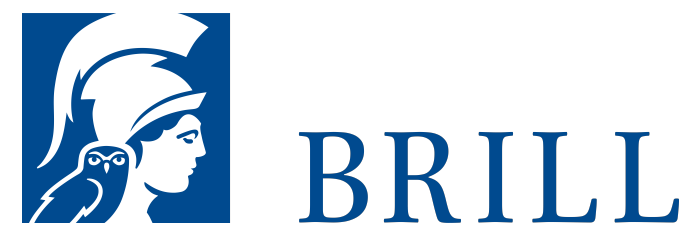

\title{
Jan van Eycks 'Ars Mystica'
}

\section{Author: Sabine Augath}

Mit Rücksicht auf die Einzigartig-keit der altniederländischen 'Bildfrömmigkeit' eröffnet sich ein neuer Blick auf die Werke Jan van Eycks, Gründerfigur der alt-niederländischen Malerei. Seine kompositionellen Kunstgrif-fe, seine vieldiskutierte Art der Symbolverwendung, die zwi-schen bedeutungsvollen 'Zei-chen' und sinnlichen 'Intensitä-ten' unentscheidbar oszilliert, wie auch erstmals aufgedeckte iko-nographische Besonderheiten seiner Bildwelt erweisen die enge Bindung des Malers an die zeit-genössische Spiritualität. Insofern ist der ihm unterstellte virtuos gestimmte Referenzverzicht sä-kularer Prägung zweifelhaft. Da-mit schließt die Untersuchung an die jüngst erfolgte 'religiöse Wende' im Van-Eyck-Diskurs der Kunstgeschichte an. Doch erst der hier gewählte Paradigmenwechsel, der dem Einfluß spätan-tiker Theoreme auf das mittelal-terliche Bildverständnis Rech-nung trägt, stößt vor zu einer tragfähigen „Neufundierung der van Eyck-Deutung, die sicherlich starke Beachtung verdient und sie vermutlich auch erzielen wird“ (Gottfried Boehm).

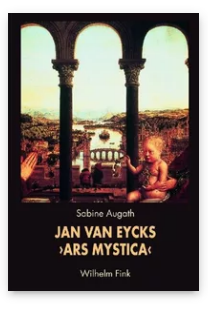

Pages: 553

Seiten, 10 farb.

Abb.

Language:

German

Subjects:

General, Art

History

Publisher: Brill |

Fink

E-Book (PDF)

Released online: 29 Oct 2019

ISBN: 978-3-

8467-4539-7

List price

USD \$131.00

Hardback

Publication date: O5 Oct 2007

ISBN: 978-3-

7705-4539-1

List price

USD \$131.0o 
For more information see brill.com

Order information: Order online at brill.com +44330 333 0049 | customerservices@brill.com Submission information: brill.com/authors

Titles published by Brill | Fink, Brill | mentis or Brill | Schöningh: +49(o)715413279216| brill@brocom.de 